\title{
メニエール病の治療効果の判定
}

\author{
時田喬 - 宮田 英雄 - 牧達夫 - 浅井 徳光 \\ 橋本 正彦・前田正徳・棚橋 聰子
}

\section{Evaluation of Effects of Treatment of Meniere's Disease}

\author{
T. Tokita, H. Miyata, T. Maki, N. Asai \\ M. Hashimoto, M. Maeda and S. Tanahashi \\ (Gifu Univ.)
}

We report herein the examinations required for evaluation of the effects of treatment of Meniere's disease. Prior to the discussion, it is indispensable to clarify the design of the treatment. In the treatment, the authors take into consideration the following three subjects: (1) treatment of vertigo, (2) treatment of damage to the inner ear, and (3) treatment of recurrence of attacks of vertigo.

(1) For evaluation of effects of treatment of vertigo in attacks and dizziness in the chronic stage of the disease, complaints of vertigo and spontaneous nystagmus as objective evidence of vertigo should be investigated. Furthermore, righting reflex and deviation test should be performed in order to demonstrate the mechanism of improvement of the vertigo. Despite the improvement obtained by inhibitory effects of drugs on the vertigo, the righting function and deviation phenomenon remain unchanged. On the contrary, when the pathological condition of the inner ear is healed there is an improvement of these signs.

(2) Effects of the treatment for damage of the inner ear are evaluatc $d$ by hearing and caloric tests. In cases where the labyrinthine excitability is not reversible, compensatory process of balancing activity of the body should be examined using the standing test, tests for spontaneous nystagmus, deviation and caloric tests and tests for postrotatory nystagmus. Disappearance of spontaneous nystagmus and deviation phenomenon reveal a recovery of static balance of the vestibular system. Disappearance of asymmetry of postrotatory nystagmus indicates a restoration of balance in the kinetic labyrinthine reflexes.

(3) Recurrences of attacks of vertigo are treated on the basis of the results of examination of etiologic factors of Meniere's disease in each patient. Effects of this treatment should be eval:ated by long-term follow-up of the vertiginous attacks.

$$
\text { はじめに }
$$

メニエール病の治療効果判定によ゙んな検查が必要かを検㣥するためには，まず，メ二エール病の 
治療をどのような方針で行うかを明確にしておく必要がある。

私どもはメニエール病の治療においては,

1.めまい（発作時，間歇期）に対する治療

2.内耳障害（難聴，半規管反応低下）に対する治療

3. めまい発作の反覆に対する治療（素因検査成績に基づいて計画する）

の 3 つを考慮して行う必要があると考えている. 従って, 治療効果の評価むてれに対応して行う必 要がある。

\section{I めまいに対する治療の効果判定}

患者が自覚し, 訴えているめまいを治療対象 とした時，その効果を評価するには次の検查が 必要である。

1.めまいについての問診

2. めまいの他覚的所見の観察 自発眼振検査

3. めまい改善の内容の検討 立直り反射検査 視運動性眼振検査 温度眼振検査

1. めまいに対する治療は発作時のめまい, 間歇期の持続性めまいを軽減, 消失せしめるて とを目的としている. 従ってての治療効果の判 定には，第一に患者が自覚し，訴えていため まいに効果があったか否かを問診する必要があ る. 発作時のめまいを対象とした場合，めまい は数分より数時間の間に自然に変動するあのな ので, 効果は短時間の間に得られなければなら ない。注射, 与薬㨁後より分単位の経時的観察 が必要である。乙の場合, 自然経過によるめま い経過と薬剤による改善と区別し難いこともあ るが, 与薬との時間的関係, 薬効が失われる頃 のめまいの再現などが鑑別の手掛りとなる．間 歇期のめまいを対象とした場合，そのめまいは 多く持続性なので, 週単位の観察が必要であ る.

2. 患者の自覚するめまいの変化を問診で把 握するのみでは効果判定に客観性がそしい。自 発眼振はめまいの他覚的所見として, めまいの 消長を客観的に把握するのに最む適している。

3. 与薬によりめまいが軽減し, 自発眼振が
減少しても，それが薬剂の，(1)前庭系への抑制 作用による場合と，(2)機能改善作用による場合 がある．たとえば，クロールプロマジンは発作 時のめまいに有効であり, 眼振抑制作用む強い が, この効果は内耳の病的状態を治して得られ たものではない。一方, メイロン, 星状神経節 遮断は内耳の血行を改善し, 病的状態を回復せ しめて, めまい, 自発眼振を消退させる作用が 期待される. めまい軽減に際して, この内容を 把握するには平衡機能の検查である立直り反射 検査が有用である。抑制作用による場合は立直 り機能の改善は得難いが, 機能回復による場合 は立直り機能が改善する。

4. 視運動性眼振は自発眼振減弱, 消失の内 容を把握するのに役立つ。自発眼振の減弱, 消 失が内耳機能の回復によるものであれば視運動 性眼振の抑制はないが，眼振抑制作用によるも のであれば視運動性眼振む抑制される。眼振所 見よりみれば, 病的眼振である自発眼振は消失 するが，生理的眼振である視運動性眼振は抑制 されない治癒状態を得ることが望まれる。

5 . 温度眼振検查はめまいの回復, 自発眼振 の軽減, 消失が, 内耳機能の回復によるものか 中枢の代償によるものか判定するのに役立つ。 発作により生じた内耳の反応性低下が正常に戻 り, めまい, 自発眼振が改善することが望まれ るが，内耳の反応性は低下したままで中枢の代 償作用によりめまい, 目発眼振の消失が得られ る. この内容の把握が必琶と考えるのである。 症例 1 (図 1)。発作時のめまいに対しメイ ロン $40 \mathrm{ml}$ 注射することによりめまいが峄減した 
32 才 女 左メニエール病

48. 10.2

$8: 20$

回転性めまい

就床
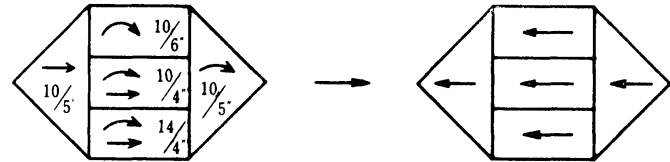

図।めまい発作に対する治療

例である。注射直後より自発眼振が逆転してい る。乙の急激な眼振所見の変化はめまいの改善 が自然経過によるものでなく薬剤によるもので あること，薬剂投与による血流改善が内耳の病
的状態を改善せしめ，めまいを軽減せしめたこ とを示䙂している。眼振所見によりめまい改制 の内谷老他觉的に把握しえている.

症例 2（図 2)。間歇期のめまいに対する治 療効果を徽察したものである。めまいの消失が 䫒位眼振の消失で他覚的にも把握しえている。 立直り機能の改善はこのめまいの改善が薬剂で めまい・眼振を抑制することによりえられたむ のでなく，機能回復によるものであることを示 す。しかし，左耳の温度反忍低下が残っている ことは，めまい・平衡障圊の回復が内耳機能の 完全な回復によるものでなくけ枢性代償による むのであること示している。

\section{II 内耳障害に対する治療の効果判定}

次の検査が必要である.

1. 難聴に対し聴力検査

2. 半規管反応低下に対し温度検查
3. 中枢性代償の把握

a 静的平衡：自発眼振，偏倚検笨

b 動的平衡：问転後眼振左右等

口50才男 左メニエール病

51. 2.26

浮動性めまい持続
アプラクタン
51. 5.13

めまい消失
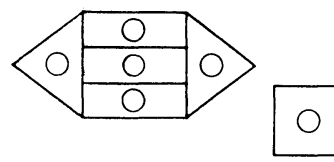

両脚起立

マン起立

単脚起

右足立 安定

安定
左足前

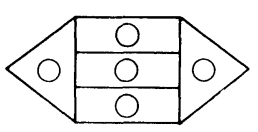

\begin{tabular}{l|l|l|}
\hline & $\overline{10} / 26^{\prime \prime}$ & $\overline{10} / 12$ \\
\hline
\end{tabular}

開閉

やや不安定

7"在

5"左

4 5 "毎接休

2 "毎接床

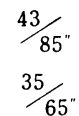

$60 / 75^{\prime \prime}$

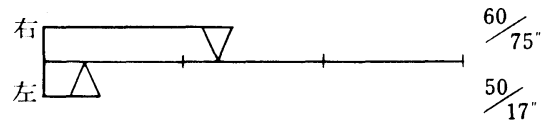

$0 "$
$60 "$

$120 "$ $180^{\prime \prime}$

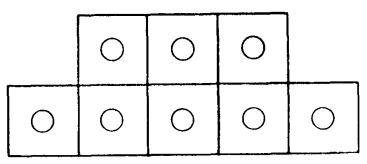

開閉

安定安定

安定 安定

安定安定

安定接床 3 回

安定安定
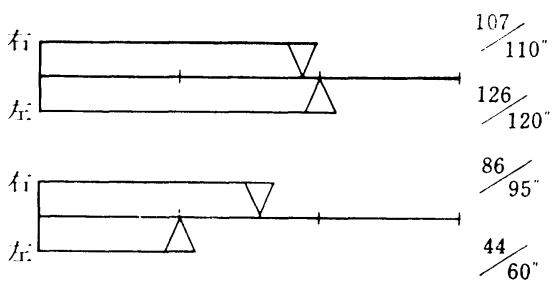

図 2 間歇期の持続性めまいに対する治療 
44才男布入二エール病 右星状神経節遮断術 (ビタノイリン $50 \mathrm{mg}$ 20\%ロジノン $20 \mathrm{ml}$
50.3 .31

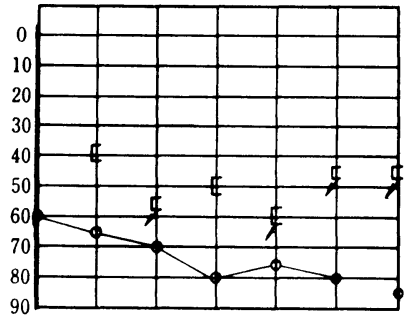

50.4 .3
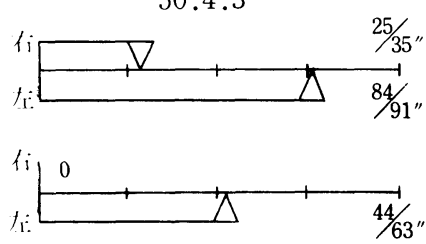

$60^{\prime \prime}$

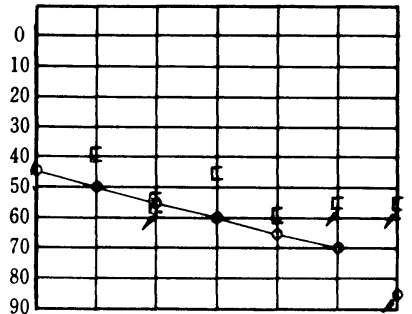

50.5 .19
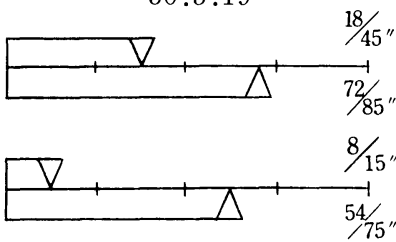

50.10 .16

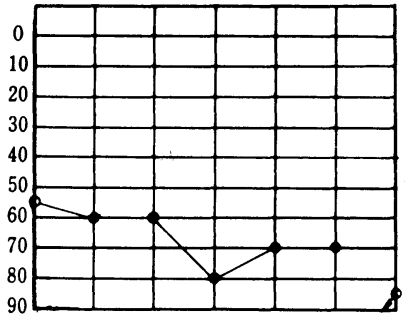

50.12 .11

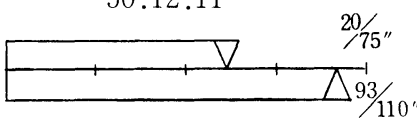

110

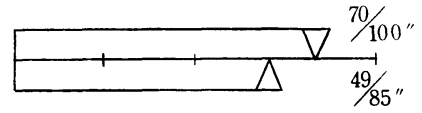

図 3 内耳障害に対する治療

57 才男 有メニエール病 40.8 超音波手術

術後翌日〜 10 H

起立 開眼 中等度障害

閉眼 高度障害

書字左 $30^{\circ}$
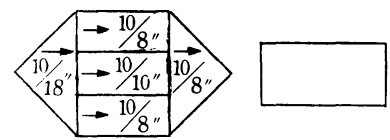

冷

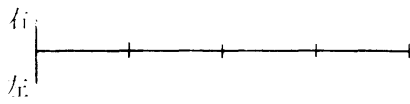

温

\section{回転後眼振}

(バラニー法)
3 力月

安定

中等度障害

右 $4^{\circ}$
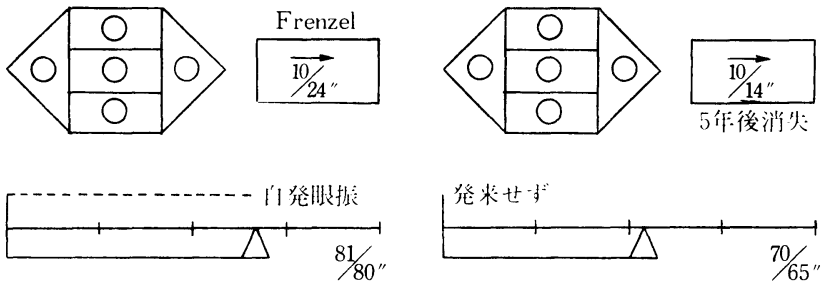

発来せ一゙

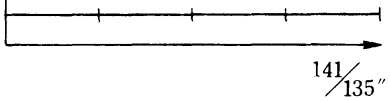

有[间転 $45 / 18$ "

们体台: 28/11"
1 年:

安定

中等度障害

右 $5^{\circ}$
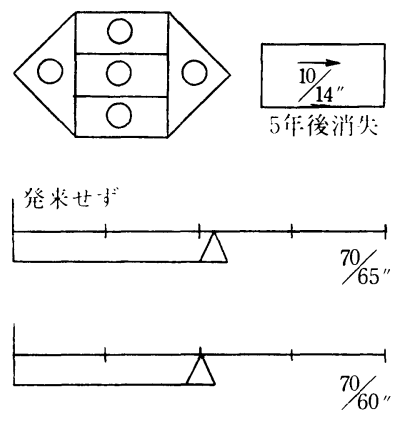

$58 / 17^{\prime \prime}$

$34 / 14^{\prime \prime}$

図 4 迷路反応垡失が固定した例の治癒過程

温度眼振のj向優位性

1. 内耳障害に対する治療効果を聴力検査, 温度検査にて観察することには問題がないが,
メニエール病の聴力障害は域值の変動が特徵で あり，自然経過による変動と治療による効果と を区別することは必ずしも容易でない，半規管 
反応についても同様に考えられる。各症例にお いて问然絴過を把握し, 治療効果による変化亡 侧する必要がある。

2. 半規管障售が闻走し, 温度反必の回復が 剘待されない埸合, 中枢代償の状態の把握が必 要となる。前庭核與奮性の平衡（静的灭衡）は 日発眼振・偏倚で観察できる。加速度刺激に対 する答の平衡（動的平衡）は回転後眼振の左: 右湿度眼振の今们優位性の变化で把握し得 る。

症例 3（図 3)。内耳障昱に対する治療効果 の検客を六す。聴力は回復していない，温度反 忍の左右差は消失し, 半規管障帮は回復したと 判定しうる。

症例 4（図4）。超音波手術後めまい発作が 消失した例である（観察期間 13年）。本例は㥙 力損失は $64 \sim 71 \mathrm{~dB}$ に固定し, 術後温度反応が 喪失しているので, 迷路反応が回復しないまま 同定した場合の治癒過程を示している。術後 10 日までは立直り障害, 偏青（四肢の筋緊張の不 均衡), 自発眼振 (腿筋緊張の不均衡) が認め
られている。術後 3 力月にて偏書, 白発眼振は 消失し叫肢, 眼の筋緊張の不均衡が代償され, 静的平衡が回復している。乙の侍期においても 温度眼振の D P, 回転後腿振の左右淁が認めら れ, 刺激に対する迷路反応 (動的平衡) には不 均衡が存する。 1 年後は温度眼振の D P 消失 し, 同転後眼振の左右差屯消失し動的平衡が元 られている。 Fisch (1973) の述べる中枢性代 償による前庭核レベルの動的平衡がえられたて とが何える。本例はめまい発作む消失し, 静的 ・動的平衡も回復し一つの治癒状態をえたとい いうる。しかし，静的・動的状態がえられたて とが直ちにめまい発作反覆の消失, メニエール 病の治癒に結びつくわけではない。本例では温 度反忍が㳖失したことによりめまい発作は反覆 しないと判定し，乙れが長期観察で裏付けられ ているが，迷路反応が残存した例において内耳 に病的状態が生ずればめまいは当然出現する。 めまい発作の反覆に対する治療効果は迷路反応 啔失例以外では次に述べる長期観察が不可欠で ある。

53才男 事務 左メニエール病

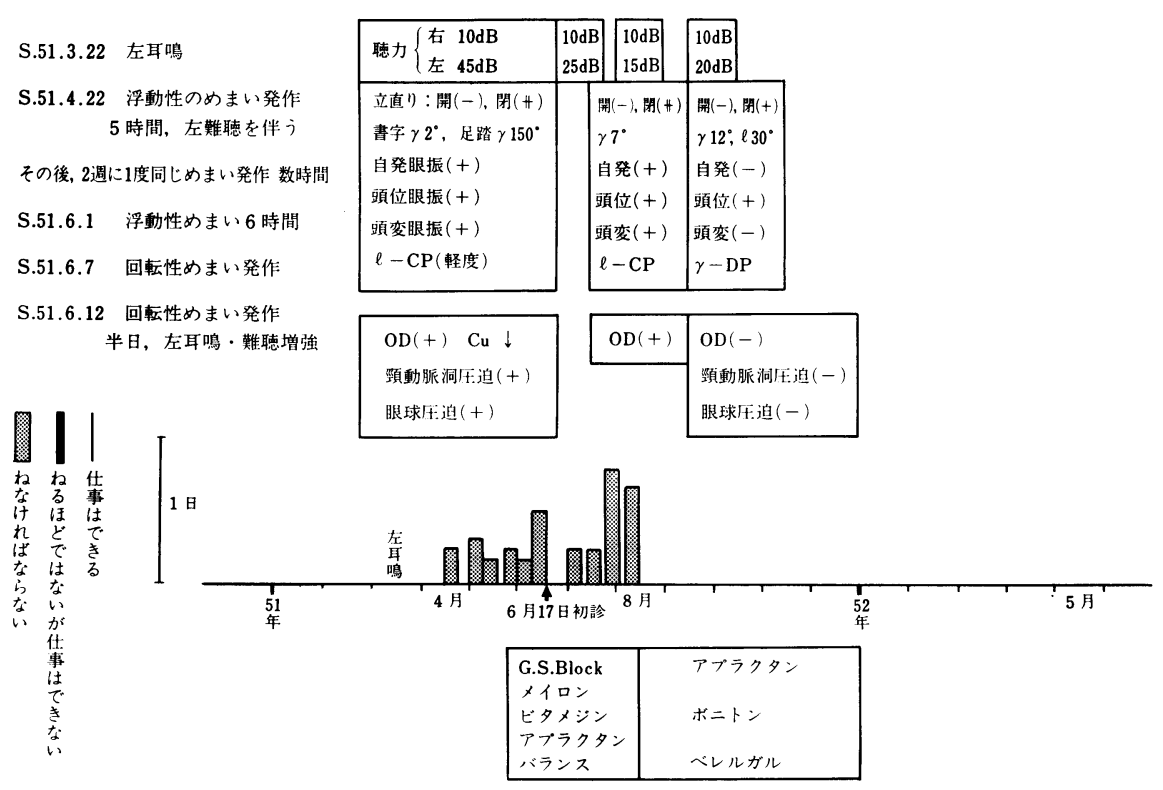

図 5 めまいの反覆性に対する治療 


\section{IIIめまい発作の反覆に対する治療効果の判定}

めまい発作の反鿉に対しては，絜因検査成績 に基づいて治療を行うが，その効果の判定は， 長期に亘る下乱の事項を吣心する恥力，平衡 機能検査によって行う必要がある。

1. めまい発作の反覆状態の把握 発作頻度，間隔，程度，持続，性質

2. 素因検查

1.メニエール病例の治療在行い，発作を繰 返さないようになっても，「今後発作は起こら ない」ということは極めて困難である。私ども が，現在これをいい得ているのは超音波手術を 行い温度刺激に対する反心を垡失せしめ得た为: 例のみである。現在，治療により発作嚬度が娍 少あるいは発作の程度が軽くなったものを改善 とし，めまい消失は観察期間をつけて示すのが 適当之考えている。

2.メ二エール病例では素因検查で循環系， 自律神経系，代謝系，頸部等に異常在認める例 が多い。乙れらの素因に対する治療効果とめま

メニエール病の治療，めまいの治療という場 合，その中に含まれる内容はいろいろである。

発作時のめまいの治療である場合，間歇期の めまいの治療である場合，発作の繰返しの治療 である場合がある。

また，治療の対象となっているものが，患者 の自覚するめまいそのものである場合，めまい を起す原因となっている内耳障害である場合， 内耳障害の原因となっている循環障害, 自律神 経障寈，代謝障青，閒脳障害などである場合が ある・

薬剂の面からみても, めまい楽剂の帆は, めまいそのもの在抑える薬も, めまい在起して いる内耳の病的状態在治す薬屯，全身的異常に 対する萫も含まれている。

治療効果を把握するための平衡機能検查の面 からみても，各種の検査がもつそれぞれの意義
い発作:頻度の関係なよ゙も明確にする必要がある が命後の閭題と考えている.

为例 5 （困 5 ）。素内検査成績に基づいて治 潦を行い，めまい発作の反覆に対する効果を検 讨した結果を示す。 51 年 4 月より 8 月にかけ问 転性めまい発作:を反覆しているが，治療開始 (6月) 後約 2 力月でめまい発作柿さまり， 約 1 年めまい発作より解放されている。めまい 発作の消失が自然経過によるものか否か評価は 困奞である。また，メ二エール病においては1 作以上の無発作:期閪在拈いて発作在来すととが 少くない (Haye and Quist-Hanssen, 1976) のでこれをもって治楒とするとともできない. 素因検查成績の改善，4月から8月にかけての 每月の発俳の消失より効果があったととが推定 されるが，めまい発作汶対する治療効果の評 価，判定は更に長剘倠祭例の皘み重ねに基づい て検垨さるべきと考えている。

察

を無視して偑则に取り报かわ扎ていることがあ る.

これらの混乱を少なくするために，私よ゙も （時田，1964）は，メ二エール病の治療を， i）めまいに対する治療，ii）内耳障害に対する 治療， iii）めまい発仡扳覆に対する治療と整 理するのが良いと考える。乙れらの治療が互い に関連することは当然であり，最終的には全体 として総合的に治療効果を把握するととが必要 であるが，治療少針を站てるにあたって，薬剂 の潩択にあたって，効果判定にあたって，三者 を意識的に区別するととが可能であるし，治療 法, 治療効果老整理して考え得る点で利点が多 い亡考えている（时田他，1966）.

な技，治療効果の判定にあたっては二重盲検 法が必桉とされることが多いが，自然経過が明 確でなく，症状の变動することが特徴であり， 
変動の状態が個々の症例で異なるメ二エール䅧 では信頼のおける二重盲検法は甚だ行い難いよ うに思われる。特に，発作反覆に対する治療效 果のごとく，長期に亘る観察を岸するむのでは
二車盲検法は特に困難である。きめ紐かい自覚

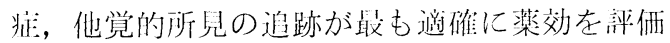
し得ると考える。

\section{結}

語

メニエール病の治療にあたっては，1）めまいに対する治療，2）内耳障㫪に対する治療，3） めまい発作:の反澓に対する治療の 3 つを考虑する必要のあるてと，各々の治療効果の判定にあたっ ては, めまいに対する問診，各種平衡機能検査，素因検査，長期観察をその各々が持つ意義を考慮 して行い，効果の内容を充分把握すべきことを述べた。

\section{参 考 文 献}

1) Fisch, U. : The vestibular response following

3) 時田 喬：内耳性めまいの素因の検査と治療 第 unilateral vestibular neurectomy. Acta Otolaryngol. $76: 229 \sim 238,1973$.

2) Haye, R. and Quist-Hanssen, Sv. : The natural course of Meniere's disease. Acta Otolaryngol. $82: 289 \sim 293,1976$. 65回日耳鼻総会シンポジウム．別刷, 1964.

4) 時田 喬, 他：めまい治療効果判定の検査（附メ 二エール病治療の遠隔成績) 耳鼻臨床 $59: 139$ 152, 1966 . 